DOI: 10.22630/EIOGZ.2014.108.42

Zeszyty Naukowe Szkoły Głównej Gospodarstwa Wiejskiego

Ekonomika i Organizacja Gospodarki Żywnościowej nr 108, 2014: 89-101

Anna Sammel

Wydział Biotechnologii i Hodowli Zwierzat

Zachodniopomorski Uniwersytet Technologiczny w Szczecinie

\title{
Rodzinne gospodarstwa agroturystyczne na obszarach wiejskich województwa zachodniopomorskiego
}

\section{Wstęp}

Rolnictwo, należące do jednego z najstarszych obszarów aktywności człowieka, przyczyniło się na przestrzeni wieków do istotnych zmian gospodarczych i społecznych na naszej planecie. Pierwsze gospodarstwa rolne prowadzone przez wielopokoleniowe rodziny były najczęściej samowystarczalnymi podmiotami. Wraz z rozwojem cywilizacyjnym zaistniała jednak potrzeba ich otwarcia na potrzeby żywieniowe zwiększającej się populacji i włączenia się w mechanizm wymiany produktów rolnych na rynku [Runowski 1996, s. 7]. W drugiej połowie XX wieku w wielu wysoko rozwiniętych regionach świata dokonano kolejnych przemian w strukturze globalnej gospodarki i rolnictwo przestało być jej dominująca gałęzią. Przyczyniła się do takiej sytuacji m.in. specjalizacja i wzrost wydajności produkcji gospodarstw rolnych, zmniejszenie liczby osób zatrudnionych w tym sektorze oraz rozwój przedsiębiorczości, który został zdefiniowany jako agrobiznes [Knecht 2009, s. 27-29]. Rolnictwo traktowane jako główna gałąź gospodarki na obszarach wiejskich przestało już być najważniejszym źródłem dochodu dla zamieszkujących je osób. Nastąpił także znaczny spadek udziału rolnictwa w wytwarzaniu produktu krajowego brutto. Zaistniała w związku z tym pilna potrzeba aktywizacji rolników w celu poszukiwania alternatywnych możliwości zarobkowania. Znalazło to swoje uzasadnienie w idei wielofunkcyjnego rozwoju obszarów wiejskich, który zaleca wprowadzanie w ich obrębie nowych funkcji pozarolniczych: produkcyjnych, handlowych oraz usługowych. Potencjalnym źródłem dochodów dla mieszkańców wsi oraz właścicieli rodzinnych gospodarstw rolnych stał się także ruch turystyczny i rozwój turystyki wiejskiej oraz agroturystyki. 


\section{Cel i metodyka badań}

Ze względu na systematycznie wzrastające znaczenie turystyki dla zrównoważonego rozwoju obszarów wiejskich, niniejszy artykuł ma na celu analizę funkcjonowania rodzinnych gospodarstw agroturystycznych w województwie zachodniopomorskim. Realizacja założonego celu badawczego przeprowadzona została na podstawie analizy wtórnych materiałów źródłowych oraz wyników badań terenowych z użyciem kwestionariusza ankiety prowadzonych w latach 2001-2003 i zweryfikowanych w 2013 roku poprzez obserwację pośrednią z wykorzystaniem baz danych oraz indywidualnych stron internetowych gospodarstw agroturystycznych, która pozwoliła uaktualnić wcześniej zgromadzone informacje. Objęto nimi 177 gospodarstw agroturystycznych ${ }^{1}$, w których prowadzona była działalność rolnicza - związana z produkcją roślinną i/lub zwierzęca, a świadczenie usług agroturystycznych traktowano jako działalność dodatkową. Ze względu na brak aktualnych w 2013 roku danych w sieci na temat kontynuacji lub zawieszenia działalności agroturystycznej, z 16 właścicielami przeprowadzono dodatkowo wywiad telefoniczny. Z czterema osobami nie zdołano się skontaktować i uznano, że nie prowadzą wcześniej podjętej działalności.

\section{Wyniki badań}

\section{Turystyka wiejska i agroturystyka jako przedsiębiorczość rodzinna na obszarach wiejskich}

Rozwój ekonomiczny obszarów wiejskich ukierunkowany jest na nowe, alternatywne sposoby wykorzystania gospodarstw rolnych i gospodarczej aktywizacji ich mieszkańców. Duże możliwości związane są z rozwojem różnorodnych form turystyki zrównoważonej. Coraz większe zainteresowanie nie tylko w Polsce, ale również w innych państwach europejskich wzbudza turystyka wiejska, która definiowana jest jako działalność związana ze świadczeniem usług turystycznych na obszarach wiejskich przez osoby nieprowadzące działalności rolniczej [Dębniewska i Tkaczuk 1997, s. 16-17]. Popularna jest również agroturystyka, jako forma wypoczynku odbywającego się na terenach wiejskich o charakterze rolniczym, oparta o bazę noclegową i aktywności rekreacyjne związane

\footnotetext{
${ }^{1}$ Obecnie funkcjonuje na terenie województwa zachodniopomorskiego - według różnych źródeł - około 750-800 tego typu obiektów.
} 
z gospodarstwem rolnym lub równoważnym i jego otoczeniem przyrodniczym, produkcyjnym oraz usługowym [Drzewiecki 2009, s. 13]. Umiejętność obsługi ruchu turystycznego przez mieszkańców wsi związana jest $\mathrm{z}$ rozwojem ich przedsiębiorczości jako postawy i sposobu działania polegającego na gotowości podejmowania nowych przedsięwzięć oraz na wykazywaniu inicjatywy $w$ ich poszukiwaniu i wdrażaniu [Duraj 2000, s. 15-16].

Firmy rodzinne (family business, FB) były i są podstawą światowej gospodarki. Ze względu jednak na brak jednoznacznej definicji tego pojęcia $\mathrm{w}$ wielu państwach, niemożliwe jest np. chociażby do celów statystycznych dokładne określanie ich liczby [Sten 2006, s. 16] lub podjęcie szerszych, często interdyscyplinarnych badań naukowych nad tym istotnym nie tylko ze względów ekonomicznych podmiotem. Coraz częściej bowiem zagadnieniami funkcjonowania firm rodzinnych interesują się przedstawiciele nauk społecznych, m.in. socjologicznych (firma funkcjonuje w środowisku, a jeżeli jest wieloosobowa, to zachodzą pomiędzy zatrudnionymi w niej osobami różnorodne interakcje) lub psychologicznych (m.in. z zakresu psychologii społecznej lub zarządzania).

Według statystyk, firmy rodzinne stanowią około $80-90 \%$ wszystkich przedsiębiorstw na świecie (badania prowadzone w 2009 roku wykazały, że firmy rodzinne stanowią aż 1/3 wszystkich polskich przedsiębiorstw sektora MMSP) [Badania firm rodzinnych. Raport końcowy 2009, s. 67] i w związku z tym nie są one jednorodną, łatwą do scharakteryzowania grupą, pomimo tego, że od dawna podejmowane są próby ich klasyfikacji.

W literaturze brak jest precyzyjnej definicji przedsiębiorstwa rodzinnego. Przy jego formułowaniu zazwyczaj brane są pod uwagę różnorodne obiektywne oraz subiektywne kryteria, takie jak system zarządzania [Donelley 1964, s. 93-105], rodzinna struktura własności [Fleming 2000, s. 105-107], mniej sformalizowany charakter przepływu informacji, wielkość, wyznawany system wartości, branża, zaangażowanie więcej niż jednego pokolenia w funkcjonowanie firmy, kultura organizacyjna [Koźmiński i Piotrowski 1995, s. 299], co tworzy razem tzw. specyficzne wewnętrzne zasoby wbudowane w firmę jako rezultat zaangażowania rodziny [Socik 2012, s. 93-104]. Często przyjmuje się, że jest to przede wszystkim firma, która postrzega samą siebie jako firmę rodzinną [Sten 2006, s. 16]. Mając na względzie powyższe kryteria, do firm rodzinnych możemy zaliczyć również rolnicze gospodarstwo rodzinne prowadzone osobiście przez rolnika indywidualnego i jego rodzinę, w skład którego wchodzi od 1 do 300 hektarów użytków rolnych [Stawicka 2010, s. 110-118]. Szczególnym przykładem przedsiębiorczości na obszarach wiejskich są także gospodarstwa agroturystyczne, których podstawowym celem funkcjonowania jest działalność ukierunkowana na zysk [Dorocki, Szymańska i Zdon- 
-Korzeniowska 2012, s. 45-60]. Agroturystyka jest specyficzną formą działalności, której podjęcie wiąże się nie tylko z odpowiednimi cechami osobowościowymi członków rodziny, ale także z ich dyspozycyjnością i chęcią przyjęcia nowych obowiązków. Od ich zaangażowania będzie bowiem w dużej mierze zależał ostateczny kształt i sposób funkcjonowania obiektu [Knecht 2009, s. 99-100].

\section{Gospodarstwa agroturystyczne jako firmy rodzinne na obszarach wiejskich województwa zachodniopomorskiego}

Ze względu na liczne walory naturalne $\mathrm{i}$ antropogeniczne od wielu lat w gospodarce województwa zachodniopomorskiego dominuje sektor turystyki [Strategia rozwoju... 2010, s. 36-45]. Znajduje się tu największa liczba miejsc noclegowych w Polsce w obiektach zbiorowego i indywidualnego zakwaterowania (17,8\%) [Turystyka... 2013, s. 53], co sprawia, że teren ten jest w czołówce regionów turystycznych Polski, a działalność związana z obsługą ruchu turystycznego jest źródłem zatrudnienia wielu jego mieszańców. Ofertę turystyczną uzupełniają od wielu lat także gospodarstwa agroturystyczne (tab. 1).

Tradycje związane $\mathrm{z}$ wypoczynkiem na wsi znane są w tym rejonie Polski od wielu lat jako tzw. wczasy pod gruszą. Agroturystyka zajmuje również istotne miejsce w dokumentach strategicznych gmin, powiatów i województwa, ponieważ obszary wiejskie zajmują $94 \%$ jego powierzchni. Najwięcej obiektów znajduje się jednak w pasie nadmorskim i na pojezierzach, co ma związek z występującymi tam walorami naturalnymi, antropogenicznymi i specjalistycznymi oraz zagospodarowaniem turystyczno-rekreacyjnym ${ }^{2}$.

W wyniku przeprowadzonych badań stwierdzono, że o 10,7\% uległa zmniejszeniu liczba obiektów prowadzących działalność agroturystyczną w 2013 roku w porównaniu z danymi uzyskanymi w latach 2001-2003 ${ }^{3}$. Najwięcej gospodarstw zaprzestało działalności w powiecie kamieńskim ( 7 obiektów). Ustalono, że spośród 19 osób, które nie prowadzą już działalności agroturystycznej, w 9 przypadkach były to względy osobiste (śmierć właściciela, sprzedaż obiektu, zmiana miejsca zamieszkania, emigracja, nowe źródło zatrudnienia).

\footnotetext{
${ }^{2}$ Rozwój tej formy turystyki - wbrew definicji - widoczny jest także w dwóch miastach na prawach powiatu: w Świnoujściu oraz w Szczecinie, ponieważ w ich obrębie zlokalizowane są również użytki rolne.

${ }^{3} \mathrm{~W} 2002$ roku tylko 2 osoby deklarowały, że nie planują kontynuowania tego typu działalności z przyczyn losowych.
} 
Tabela 1

Liczba objętych badaniami gospodarstw agroturystycznych w powiatach województwa zachodniopomorskiego w latach 2001-2003 oraz w 2013 roku

\begin{tabular}{|c|c|c|c|c|}
\hline \multirow{3}{*}{ Powiat } & \multicolumn{4}{|c|}{ Gospodarstwa agroturystyczne objęte badaniami } \\
\hline & \multicolumn{2}{|c|}{$\begin{array}{l}\text { w latach 2001-2003 } \\
\qquad(\mathrm{N}=177)\end{array}$} & \multicolumn{2}{|c|}{$\begin{array}{c}\text { w } 2013 \text { roku } \\
(\mathrm{N}=158)\end{array}$} \\
\hline & $\begin{array}{c}\text { liczba funkcjonujacych } \\
\text { gospodarstw }\end{array}$ & $\begin{array}{l}\text { \% ogólnej } \\
\text { liczby }\end{array}$ & $\begin{array}{l}\text { liczba funkcjonujących } \\
\text { gospodarstw }\end{array}$ & $\begin{array}{l}\text { zakończenie } \\
\text { działalności }\end{array}$ \\
\hline Białogardzki & 0 & 0,0 & 0 & 0 \\
\hline Choszczeński & 10 & 5,7 & 9 & 1 \\
\hline Drawski & 26 & 14,7 & 25 & 1 \\
\hline Goleniowski & 5 & 2,8 & 5 & 0 \\
\hline Gryficki & 8 & 4,5 & 8 & 0 \\
\hline Gryfiński & 9 & 5,1 & 7 & 2 \\
\hline Kamieński & 34 & 19,2 & 27 & 7 \\
\hline Kołobrzeski & 2 & 1,1 & 2 & 0 \\
\hline Koszalin* & 0 & 0,0 & 0 & 0 \\
\hline Koszaliński & 15 & 8,5 & 14 & 1 \\
\hline Łobeski & 7 & 4,0 & 6 & 1 \\
\hline Myśliborski & 2 & 1,1 & 2 & 0 \\
\hline Policki & 4 & 2,3 & 3 & 1 \\
\hline Pyrzycki & 1 & 0,6 & 1 & 0 \\
\hline Sławieński & 26 & 14,7 & 25 & 1 \\
\hline Stargardzki & 8 & 4,5 & 7 & 1 \\
\hline Szczecinecki & 6 & 3,4 & 6 & 0 \\
\hline Szczecin* & 2 & 1,1 & 1 & 1 \\
\hline Świdwiński & 2 & 1,1 & 2 & 0 \\
\hline Świnoujście* & 2 & 1,1 & 1 & 1 \\
\hline Wałecki & 8 & 4,5 & 7 & 1 \\
\hline Ogółem & 177 & 100 & 158 & 19 \\
\hline
\end{tabular}

*miasta na prawach powiatu

Źródło: Opracowanie własne. 
Gospodarstwa agroturystyczne w województwie zachodniopomorskim funkcjonują w sąsiedztwie walorów, które podnoszą atrakcyjność całego terenu i umożliwiają organizowanie $\mathrm{w}$ jego obrębie różnorodnych form wypoczynku i rekreacji ${ }^{4}$. W latach 2001-2003 największą liczebnie grupę stanowiły obiekty, których powierzchnia gruntów wynosiła maksymalnie do 5 ha $-28,8 \%$ ogółu respondentów, najmniej było natomiast gospodarstw o powierzchni powyżej 50 ha $-7,9 \%$ ogółu badanych. Uzyskane wyniki wskazywały na to, że tego typu działalnością zajmują się przede wszystkim właściciele małych gospodarstw rolnych, którzy poszukują możliwości uzyskania dodatkowych źródeł dochodu ${ }^{5}$.

Podstawowym składnikiem oferty turystycznej jest zakwaterowanie. Obecnie objęte badaniami obiekty $(\mathrm{N}=158)$ oferują około 2100 miejsc noclegowych. Podstawowy rodzaj bazy noclegowej stanowią, tak jak przed laty, pokoje gościnne w domach rolników (dostępne są w 140 obiektach, gospodarze wynajmują od 3 do 10 pokoi o zróżnicowanym standardzie oraz cenie, która mieści się w przedziale od 20 do $100 \mathrm{zl})^{6}$. Świadczy to o tym, że obiekty te funkcjonują jako gospodarstwa rolne, a działalność związaną z obsługą ruchu turystycznego traktują jako dodatkowe źródło dochodu lub istnieją jako zarejestrowane podmioty prowadzące własną działalność gospodarczą. Dodatkowo na terenie posesji można ustawić namiot, mieszkać w samodzielnym domu (9 obiektów)

\footnotetext{
${ }^{4}$ Misja rozwoju województwa do 2020 roku opiera się na stworzeniu warunków do zrównoważonego rozwoju bazującego na konkurencyjnej gospodarce i przedsiębiorczości mieszkańców oraz aktywności społecznej przy optymalnym wykorzystaniu istniejących zasobów poprzez: a) aktywizację gospodarczą z uwzględnieniem czynników ekologicznych i obecnych funkcji województwa (gospodarka morska, turystyka, transport, przemysł, rolnictwo), b) aktywizację obszarów wiejskich na rzecz ich wielofunkcyjnego rozwoju oraz wzrostu efektywności i konkurencyjności rolnictwa [Strategia Rozwoju Województwa Zachodniopomorskiego do roku 2020, Sejmik Województwa Zachodniopomorskiego, Szczecin 2005, s. 81].

${ }^{5}$ W 2002 roku stwierdzono, że 65\% ogółu badanych obiektów powstało przed 1945 rokiem. Powierzchnia użytkowa w $85 \%$ budynków wynosiła powyżej $100 \mathrm{~m}^{2}$. Najwięcej osób prowadzących gospodarstwa agroturystyczne - zarówno wśród właścicieli, jak i współwłaścicieli pozostających w związku małżeńskim - było w przedziale wiekowym 41-50 lat (71 właścicieli i 75 współwłaścicieli) i 51-60 lat (49 właścicieli i 49 współwłaścicieli). Dwadzieścia osób samotnie prowadziło działalność agroturystyczną. Zróżnicowany był także poziom wykształcenia respondentów. Właściciele i współwłaściciele gospodarstw agroturystycznych (pozostający w związku małżeńskim) w przeważającej większości legitymowali się wykształceniem zawodowym (42 właścicieli i 47 współwłaścicieli) oraz średnim nierolniczym (40 właścicieli i 48 współwłaścicieli). Zmianom uległ - w stosunku do deklarowanego przed rozpoczęciem działalności agroturystycznej - kierunek produkcji. Zmniejszeniu uległa liczba gospodarstw zajmujących się hodowlą i chowem zwierząt, a zwiększeniu liczba gospodarstw zajmujących się produkcją roślinną oraz ogrodnictwem i rybactwem.

${ }^{6}$ Zgodnie z prawem z konieczności rejestracji działalności gospodarczej i odprowadzania podatku dochodowego zwolnione są gospodarstwa rolne prowadzące działalność agroturystyczną, w której liczba oferowanych turystom pokoi nie przekracza pięciu.
} 
lub w domku campingowym. Zrezygnowano natomiast z możliwości ustawienia przyczep campingowych (wcześniej taką możliwość oferowało 8 gospodarstw), co świadczy zapewne o tym, że ten rodzaj wypoczynku jest w województwie zachodniopomorskim już mniej popularny. Jedno gospodarstwo nie świadczy usług noclegowych - goście mogą w nim przebywać tylko jako odwiedzający jednodniowi. Wybrane elementy infrastruktury przeznaczonej dla turystów w objętych badaniami gospodarstw agroturystycznych przedstawia tabela 2 .

\section{Tabela 2}

Infrastruktura gospodarstw agroturystycznych (oferta dla turystów)

\begin{tabular}{|l|c|c|c|c|}
\hline \multirow{2}{*}{ Wyszczególnienie } & \multicolumn{2}{|c|}{ Lata 2001-2003 (N = 177) } & \multicolumn{2}{c|}{ Rok 2013 (N = 158) } \\
\cline { 2 - 5 } & liczba ofert & \% ogółu & liczba ofert & $\%$ ogółu \\
\hline Parking & 171 & 96,6 & 152 & 96,2 \\
\hline Plac zabaw & 169 & 95,5 & 97 & 61,4 \\
\hline Możliwość korzystania z kuchni & 151 & 85,3 & 85 & 53,8 \\
\hline Grill/ognisko & 136 & 76,8 & 137 & 86,7 \\
\hline Możliwość rozbicia namiotu & 111 & 62,7 & 46 & 29,1 \\
\hline Wypożyczenie roweru & 100 & 56,5 & 87 & 55 \\
\hline Ogród przydomowy & 41 & 23,2 & 61 & 38,6 \\
\hline Boisko, kort & 29 & 16,4 & 18 & 11,4 \\
\hline Staw/jezioro & 23 & 13,0 & 21 & 13,3 \\
\hline Domki campingowe & 17 & 9,6 & 7 & 4,4 \\
\hline „Szopa biesiadna”, wiata & 10 & 5,6 & 16 & 10,1 \\
\hline $\begin{array}{l}\text { Możliwość ustawienia przyczepy } \\
\text { campingowej }\end{array}$ & 8 & 4,5 & 0 & 0 \\
\hline Basen (odkryty) & 5 & 2,8 & 6 & 3,8 \\
\hline Sauna & 4 & 2,3 & 1 & 0,6 \\
\hline
\end{tabular}

Źródło: Opracowanie własne.

$\mathrm{Na}$ terenie prawie wszystkich posesji wydzielone są miejsca parkingowe. Istotnym elementem zagospodarowania turystycznego są place lub bezpieczne tereny do zabaw dla dzieci, miejsca, w których można zorganizować ognisko lub grill oraz powierzchnie do rekreacji czynnej (np. boisko - 17 obiektów, kort tenisowy -1 obiekt, odkryty basen -6 gospodarstw) ${ }^{7}$. W 85 obiektach można skorzystać z kuchni w celu samodzielnego przygotowania posiłków często na bazie produktów zakupionych u gospodarza, a w 67 gospodarstwach oferowane jest wyżywienie podawane na zamówienie (przygotowywane są dwa posił-

\footnotetext{
${ }^{7}$ Uzyskane wyniki dotyczące wybranych elementów zagospodarowania turystyczno-rekreacyjnego świadczą o lepszym przygotowaniu obiektów dla turystów w porównaniu z innymi regionami Polski [Puciato D., Woś B., 2011: Innowacje jako forma wzbogacania oferty wybranych gospodarstw agroturystycznych w Górach Świętokrzyskich, Folia Pomer. Univ. Technol. Stetin. Oeconomica 288(64), s. 113-124].
} 
ki: śniadania i obiadokolacje, wyjątkiem jest okres świąteczny, gdy serwowane jest specjalne menu). Żadne z objętych badaniami gospodarstw nie oferuje natomiast usługi typu B\&B, która jest popularna w krajach Europy Zachodniej oraz w Skandynawii i ze względu na bliskość granicy, a także dużą liczbę turystów zagranicznych byłaby zapewne innowacyjna w stosunku do innych ofert dostępnych na rynku produktów agroturystycznych.

Województwo zachodniopomorskie ze względu na swoje położenie i niezaprzeczalne walory antropogeniczne i przyrodnicze odwiedzane jest zarówno przez turystów krajowych, jak i zagranicznych. Z badań empirycznych wynika [Sikora 2008, s. 13-20], że z usług gospodarstw agroturystycznych w Polsce korzystają przede wszystkim cztery grupy klientów: goście weekendowi i świąteczni, miłośnicy pozyskiwania runa leśnego, uczestnicy spotkań biznesowych, szkoleniowych czy konferencyjnych oraz goście zagraniczni. Analizując uzyskane wyniki stwierdza się, że w województwie zachodniopomorskim dominują obiekty typu U (gospodarstwa uniwersalne, wszechstronne - 133 gospodarstw dla rodzin, osób samotnych oraz grup) oraz typu D (gospodarstwa dla rodzin z małymi dziećmi, ale nie ma informacji, że nie przyjmowani są inni goście). Jeden obiekt można zaliczyć do typu N, ponieważ jest przystosowany do potrzeb osób niepełnosprawnych. Żadne gospodarstwo nie świadczy usług tylko dla seniorów (typ S). Czternaście gospodarstw może być traktowanych jako obiekty specjalistyczne Typu III sp (hodowla zwierząt gospodarskich) oraz 10 to obiekty typu II sb (wysoki standard).

Działalność agroturystyczna prowadzona jest w 67 gospodarstwach sezonowo, a w 91 obiektach respondenci posiadają ofertę całoroczną. Coraz więcej jest także miejsc, które zapraszają turystów również w okresie świątecznym i świąteczno-noworocznym (10 gospodarstw). W jednym obiekcie turyści mogą spędzić urlop nieodpłatnie $\mathrm{w}$ zamian za pomoc $\mathrm{w}$ codziennych pracach na rzecz gospodarstwa.

Najczęściej dostępnymi produktami, które oferowane są przyjeżdżającym do obiektu agroturystycznego turystom i odwiedzającym jednodniowym to: kontakt ze zwierzętami gospodarskimi, jeździectwo (często oferta łączona z innymi gospodarstwami) oraz możliwość wędkowania (w stawach należących do gospodarstwa lub w jego okolicy) - tabela 3. Uzyskane wyniki dotyczące produktów agroturystycznych są porównywalne do tych, które opisano w innych regionach Polski [por. Puciato i Woś 2011, s. 113-124, Dorocki, Szymańska i Zdon-Korzeniowska 2012, s. 45-60]. Zachodniopomorskie gospodarstwa oferują również

\footnotetext{
${ }^{8}$ Klasyfikacja gospodarstw została opracowana na podstawie: Jalinik M., 2005: Typologia gospodarstw agroturystycznych jako determinanta ustug, Rozprawy Naukowe Politechniki Białostockiej 123, Wydawnictwo Politechniki Białostockiej, Białystok, s. 109-115.
} 
Tabela 3

Oferta produktu przygotowanego dla turystów przez właścicieli gospodarstw agroturystycznych w województwie zachodniopomorskim (2013 rok)

\begin{tabular}{|l|c|c|}
\hline \multirow{2}{*}{ Oferta } & \multicolumn{2}{|c|}{$\mathrm{N}=158$} \\
\cline { 2 - 3 } & liczba ofert & $\%$ ogółu \\
\hline Kontakt ze zwierzętami gospodarskimi & 41 & 25,9 \\
\hline Jeździectwo & 31 & 19,6 \\
\hline Wędkarstwo & 43 & 27,2 \\
\hline Nauka nowych umiejętności (gotowanie) & 3 & 1,9 \\
\hline Organizacja imprez okolicznościowych & 17 & 10,8 \\
\hline Jazda bryczka, kuligi & 10 & 6,3 \\
\hline Zakup produktów z gospodarstwa & 36 & 22,8 \\
\hline Spływy kajakowe & 2 & 1,3 \\
\hline Wyprawy w celu obserwacji dzikich zwierząt & 2 & 1,3 \\
\hline
\end{tabular}

Źródło: Opracowanie własne.

naukę nowych lub doskonalenie posiadanych umiejętności w zakresie gotowania i przygotowywania przetworów. W jednym gospodarstwie można rozpocząć pod opieką instruktora naukę nurkowania lub uczestniczyć w polowaniu. Coraz częściej dostępne są również produkty w zakresie organizacji imprez okolicznościowych (rodzinnych, firmowych, towarzyskich).

Przygotowanie atrakcyjnego dla turysty produktu to zapewne duże wyzwanie dla rolników, którzy oprócz swojej dotychczasowej działalności związanej z produkcją i zbytem płodów rolnych, prowadzą również obiekt turystyczny. Właściciel powinien bowiem zapewnić gościom nie tylko odpowiednie warunki mieszkaniowe i bezpieczeństwo, ale przede wszystkim stworzyć „,domową” atmosferę, która w dzisiejszych czasach ma dla wielu gości niewymierną wartość. W zamian za to gospodarz może poszerzyć swoje kontakty społeczne, nawiązać znajomości, zdobyć nowe doświadczenia i kwalifikacje. Firmy rodzinne w turystyce wymagają jednak częstych kontaktów z klientami, co ingeruje w życie rodziny i może na nie wpływać w negatywny sposób [Tassopioulos 2008, s. 276]. Wielu właścicieli gospodarstw potrafi kreować atmosferę gościnności, która skutkuje budowaniem silnych relacji w odniesieniu do klientów, co zwiększa poziom ich lojalności [Dębski 2012, s. 61-76]. Specyficzny sposób zachowania, profesjonalny, ale jednocześnie serdeczny i mniej sformalizowany w porównaniu z tym oferowanym przez obsługę obiektów zbiorowego zakwaterowania należy do tzw. zasobów niematerialnych, które w znacznym zakresie wyznaczają sukces gospodarstwa i zadowolenie turystów [Presas, Munoz i Guia 2011, s. 274-284].

Właściciele gospodarstw korzystają obecnie z wielu możliwości reklamy. Oprócz tradycyjnych folderów, ulotek i wizytówek coraz częściej wybierają Internet. Własną stronę posiada 59\% obiektów i często jest ona dostępna również 
w językach obcych: angielskim, niemieckim oraz rosyjskim (23 gospodarstwa) ${ }^{9}$. Innowacją jest także aktywność rolników na serwisach społecznościowych takich jak np. Facebook lub wykorzystanie w działalności komunikatorów typu GG.

Ważnym aspektem działalności gospodarstw agroturystycznych są inwestycje. Do ich finansowania wykorzystywane są najczęściej środki własne, ale również zewnętrzne w formie funduszy unijnych. $Z$ takiej możliwości skorzystał jeden właściciel w ramach Programu SAPARD, Działanie 4: Różnicowanie działalności gospodarczej na obszarach wiejskich, Schemat 4.1: Tworzenie źródeł dodatkowego dochodu w gospodarstwach rolnych oraz 14 rolników w ramach Sektorowego Programu Operacyjnego „Restrukturyzacja i modernizacja sektora żywnościowego oraz rozwój obszarów wiejskich w latach 2004-2006", Priorytet 2: Zrównoważony rozwój obszarów wiejskich, w ramach którego do właścicieli gospodarstw agroturystycznych skierowane było Działanie 2.4: Różnicowanie działalności rolniczej i zbliżonej do rolnictwa w celu zapewnienia różnorodności działań lub alternatywnych źródeł dochodu.

Zachodniopomorskie gospodarstwa agroturystyczne, które zostały objęte badaniami w 2013 roku, funkcjonują na rynku usług turystycznych od ponad 12 lat i są prowadzone głównie przez pierwszego właściciela/właścicieli, ponieważ zaledwie w 3 przypadkach można mówić o sukcesji, w wyniku której dzieci kontynuują działalność zapoczątkowaną przez rodziców. Są to zatem typowe dla polskiej gospodarki podmioty, ponieważ średni wiek firmy rodzinnej wynosi obecnie 14 lat, a najliczniej występują firmy obecne na rynku od 11 do 20 lat [Badania firm rodzinnych. Raport końcowy 2009, s. 30]. Biorąc pod uwagę etap w cyklu życia podmiotów prowadzących działalność gospodarczą, jest to najczęściej ich faza dojrzała.

\section{Podsumowanie}

Turystyka wiejska, w tym również agroturystyka, to specyficzne formy turystyki, której założenia zgodne są z ideą rozwoju zrównoważonego. Wypoczynek na obszarach wiejskich z różnych względów jest korzystny zarówno dla turystów (wypoczynek, rekreacja, poznanie), jak i ich stałych mieszkańców (dodatkowe źródło dochodu, aktywizacja zawodowa). W przypadku funkcjonujących gospodarstw agroturystycznych ich działalność związana jest z konkretnym miejscem,

\footnotetext{
${ }^{9}$ Własną stronę posiada zdecydowanie mniej obiektów w porównaniu z tymi, które uwzględnili w swoich badaniach inni autorzy [por. Dorocki, Szymańska i Zdon-Korzeniowska 2012 s. 45-60], ale więcej niż zaprezentowanych zostało w publikacji Puciato i Woś [2011, s. 113-124].
} 
ponieważ kapitał, którym dysponująjest mniej mobilny i ogranicza skłonność do poszukiwania nowych lokalizacji [Dębski 2012, s. 61-76].

W Polsce mamy wielką różnorodność firm rodzinnych, do których należą także gospodarstwa agroturystyczne funkcjonujące w województwie zachodniopomorskim. Są to podmioty, które mimo wielu barier, zmieniającej się koniunktury na rynku i światowego kryzysu kontynuują swoją działalność, odgrywając nie tylko istotną rolę ekonomiczną, ale także społeczną ze względu na wiele wspólnych cech:

- $\quad$ są to niewielkie podmioty świadczące usługi turystyczne na obszarach wiejskich,

- mają szeroki, często międzynarodowy zasięg działalności,

- prowadzone są przez pierwsze, ewentualnie drugie pokolenie właścicieli,

- mają silny związek z lokalnym środowiskiem,

- właściciele wykazuja przedsiębiorczość i elastyczność w dostosowywaniu ofert do potrzeb rynku,

- więzi rodzinne właścicieli sprzyjają lepszej współpracy, efektywniejszej wymianie myśli i pomysłów,

- właściciele wykazują przywiązanie do wartości, tradycji i wizerunku firmy [Stawicka 2010, s. 112-113],

- widoczna jest wszechstronność świadczonych usług i pełnienie wielu ról przez rodzinę rolnika,

- w rodzinie otwarty jest system komunikacji, zarządzania i przepływu informacji,

- działalność tego typu cechuje niski stopień formalizacji i biurokratyzacji,

- inwestycje podejmowane są na zasadzie „małych kroków”, bez ryzykownych zachowań rynkowych,

- większość gospodarstw nie dysponuje jeszcze znacznym majątkiem, co nie oznacza, że biznes ten nie jest dochodowy, kieruje się on tylko wartościami, wśród których zysk w wymiarze finansowym nie jest podstawowym kryterium działalności [Andrzejewski 2012, s. 77-89].

Aktywność i przedsiębiorczość wielu objętych badaniami właścicieli nie ogranicza się tylko do prowadzenia usług turystycznych na obszarach wiejskich. Zaangażowani są oni również często w działalność handlową, usługową, edukacyjną (właściciele prowadzą kursy i szkolenia dotyczące np. hodowli wybranych gatunków zwierząt), opiekuńczo-wychowawczą (w jednym z gospodarstw powstał rodzinny dom dziecka) i społeczną. Poprzez swoją pracę przyczyniają się do gospodarczego ożywienia regionu, rozbudowy istniejącej infrastruktury, tworzą dodatkowe miejsca zatrudnienia, integrują lokalne społeczności oraz troszczą się o estetykę i dziedzictwo kulturowo-przyrodnicze obszarów wiejskich. Niestety jak pokazują badania, tylko około $30 \%$ firm rodzinnych przetrwa do 
następnego pokolenia, a zaledwie $10 \%$ do trzeciego pokolenia [Fleming 2006, s. 8]. Biorąc jednak pod uwagę nakład pracy i duże zaangażowanie właścicieli gospodarstw agroturystycznych w prowadzoną działalność, należy mieć nadzieję, że zdecydowanie więcej firm rodzinnych tego rodzaju przetrwa na rynku usług turystycznych nie tylko w województwie zachodniopomorskim, ale także w Polsce.

\section{Literatura}

ANDRZEJEWSKI M., 2012: Networking i sieci biznesowe szansq dla rozwoju polskich firm rodzinnych, Przedsiębiorczość i Zarzadzanie, t. XIII, z. 8, s. 77-89.

Badania firm rodzinnych. Raport końcowy 2009, red. A. Kowalewska, Parp, Pentor, Warszawa, s. 30, 67.

DĘBNIEWSKA M., TKACZUK M., 1997: Agroturystyka, koszty, ceny, efekty, Wydawnictwo Poltext, Warszawa, s. 16-17.

DĘBSKI M., 2012: Firmy rodzinne w budowaniu konkurencyjności destynacji turystycznych, Przedsiębiorczość i Zarządzanie, t. XIII, z. 8, 61-76.

DONELLEY R., 1964: The family business, Harvard Business Review 42 (4), s. 93-105.

DOROCKI S., SZYMAŃSKA A.I., ZDON-KORZENIOWSKA M., 2012: Polskie gospodarstwa agroturystyczne jako przedsiębiorstwa rodzinne, Przedsiębiorczość i Zarządzanie, t. XIII, z. 8, s. 45-60.

DRZEWIECKI M., 2009: Agroturystyka współczesna w Polsce, Wyższa Szkoła Turystyki i Hotelarstwa w Gdańsku, Gdańsk, s. 13.

DURAJ J., 2000: Podstawy ekonomiki przedsiębiorstwa, PWE, Warszawa, s. 15-16.

Fleming Q.J. 2000: Tajniki przetrwania firmy rodzinnej, Wydawnictwo Helion, Gliwice, s. $105-107$.

FLEMING Q.J., 2006: Tajniki przetrwania firmy rodzinnej: jak uniknać siedmiu grzechów głównych niszczqcych firmy, Wydawnictwo Helion, Gliwice, s. 8.

JALINIK M., 2005: Typologia gospodarstw agroturystycznych jako determinanta ustug, Rozprawy Naukowe Politechniki Białostockiej 123, Wydawnictwo Politechniki Białostockiej, Białystok, s. 109-115.

KNECHT D., 2009: Agroturystyka w agrobiznesie, Wydawnictwo C.H. Beck, Warszawa, s. $27-29,99-100$.

KOŹMIŃSKI A.K., PIOTROWSKI W., 1995: Zarzqdzanie. Teoria i praktyka, PWN, Warszawa, s. 299.

PRESAS P., MUNOS D., GUIA J., 2011: Branding familiness in tourism family firms, Journal of Brand Management 18(4/5), s. 274-284.

PUCIATO D., WOŚ B., 2011: Innowacje jako forma wzbogacania oferty wybranych gospodarstw agroturystycznych w Górach Świętokrzyskich, Folia Pomer. Univ. Technol. Stetin., Oeconomica 288(64), 113-124.

RUNOWSKI H., 1996: Ograniczenia i szanse rolnictwa ekologicznego, Wydawnictwo SGGW, Warszawa, s. 7. 
SIKORA J., 2008: Innowacyjność w agroturystyce polskiej - teoria i praktyka, [w:] Innowacje w rozwoju turystyki, (red.) M. Jalinik. Wydawnictwo Politechnika Białostocka, Białystok, s. 13-20.

SOCIK A., 2012: Tożsamość i wizerunek firm rodzinnych, Przedsiębiorczość i Zarządzanie, t. XIII, z. 8, s. 93-104.

STAWICKA E., 2010: Firmy rodzinne jako przykład przedsiębiorstw zarzqdzanych przez wartości, ich sens i znaczenie, Zeszyty Naukowe SGGW w Warszawie Problemy Rolnictwa Światowego, t. 10 (XXV), z. 2, Wydawnictwo SGGW, Warszawa, s. 110-118.

STEN J., 2006: Transfers of family business to non-family buyers. The selling business family perspective, Helsingfors, Helsinki, s. 16.

Strategia rozwoju województwa zachodniopomorskiego do 2020 roku, Sejmik Województwa Zachodniopomorskiego, Szczecin 2005, s. 36-45.

TASSIOPOULOS D., 2008: New Tourism Ventures. An Entrepreneurial and Managerial Approach, Juta, Cape Town, s. 276.

Turystyka $w$ województwie zachodniopomorskim w latach 2010-2012, Urząd Statystyczny w Szczecinie, Szczecin 2013, s. 53.

\title{
Family agritourism farms in rural areas in Zachodniopomorskie region
}

\begin{abstract}
In the period of transformation in Poland after 1989 the possibilities to develop individual economic activity, including family business, grew. Presently, family businesses are the basis of world economy. One of the forms of family business are agricultural family farms, managed by an individual farmer and his family. A specific type of the enterprise characterizes agritourist farms. These enterprises continue their activity, in spite of changing economic situation and world crisis, playing an important economic and social role. With regard to the meaning of this form of tourism for sustainable development of the rural areas, the aim of this paper is the analysis of functioning of family agritourist farms in Zachodniopomorskie region.
\end{abstract}


